\title{
Peran Notaris Dan Perlindungan Hukum Dalam Perjanjian Jual Beli Bekas Tanah Kas Desa Pandowoharjo Sleman
}

\author{
Ivan Novian Janitra \\ Fakultas Hukum Universitas Islam Indonesia Yogyakarta Indonesia \\ Jln. Cik Di Tiro Yogyakarta Indonesia \\ ivan.novian46@gmail.com
}

\begin{abstract}
This study aims to determine the role of a notary and legal protection for the sale and purchase of rights to land former treasury land in Pandowoharjo Village, where the formulation of the problems posed are: First, how is the legal protection for sellers and buyers in buying and selling rights to land former village treasury lands in Pendowoharjo Village which was made under-hand?; Second, what is the role of the notary in the settlement of the sale and purchase of rights over the former treasury land of Pendowoharjo Village which was made under-hand? This research is descriptive-qualitative, in which data is collected by interviewing the Sleman Regency Land and Spatial Planning Office, Pandowoharjo Village Administration, Pandowoharjo Residents and Notaries in Sleman Regency, as well as studying and reviewing laws and regulations, library books and other documents related to research. The results of this study concluded that legal protection was carried out by the Pandowoharjo Village Government by facilitating the under-hand sale and purchase to be witnessed by village officials and the Chief of Village; Additionally, the author suggests that the role of the Notary can be involved in order to strengthen the evidenciary power of the underhand agreement by legalizing the sale and purchase agreement letter of the former treasury land of Pandowoharjo Village.
\end{abstract}

Key Words: Legal protection; notary; role; transfer of rights; treasury land

\begin{abstract}
Abstrak
Penelitian ini bertujuan untuk mengetahui peran notaris dan perlindungan hukum terhadap jual beli hak atas tanah bekas tanah kas Desa Pandowoharjo, dimana rumusan masalah yang diajukan yaitu: Pertama, bagaimanakah perlindungan hukum bagi para penjual dan pembeli dalam jual beli hak atas tanah bekas tanah kas desa di Desa Pendowoharjo yang dibuat secara di bawah tangan?; Kedua, bagaimana peran Notaris dalam penyelesaian jual beli hak atas tanah bekas tanah kas desa Pendowoharjo yang dibuat di bawah tangan?. Penelitian ini bersifat deskriptif-kualitatif, yang mana data dikumpulkan dengan cara wawancara kepada Dinas Pertanahan dan Tata ruang Kabupaten Sleman, Pemerintahan Desa Pandowoharjo, Warga Pandowoharjo dan Notaris di Kabupaten Sleman. serta mempelajari dan mengkaji peraturan perundang-undangan, buku pustaka maupun dokumendokumen lainnya berkaitan dengan penelitian. Hasil studi ini menyimpulkan perlindungan hukum dilakukan oleh Pemerintah Desa Pandowoharjo dengan cara memfasilitasi jual beli di bawah tangan tersebut dengan disaksikan oleh perangkat desa dan Kepala Desa; di samping itu Penulis juga menyarankan agar peran Notaris dapat dilibatkan dalam rangka memperkuat kekuatan pembuktian perjanjian di bawah tangan dengan cara melegalisasi surat perjanjian jual beli Bekas Tanah kas Desa Pandowoharjo tersebut.
\end{abstract}

Kata-kata Kunci: Notaris; peran; perlindungan hukum; tanah kas desa; tukarmenukar hak 


\section{Pendahuluan}

Penyediaan tanah bagi pembangunan untuk kepentingan umum merupakan tuntutan yang tidak bisa dihindari oleh pemerintah. Semakin maju masyarakat maka semakm banyak tanah-tanah dibutuhkan oleh kepentingan umum. Sebagai konsekuensi dari hidup bernegara dan bermasyarakat, apabila hak milik perorangan berhadapan dengan kepentingan umum maka kepentingan umumlah yang harus didahulukan. Berdasarkan konstitusi dan bertolak dari realitas perkembangan masyarakat, pengadaan tanah untuk kepentingan umum tidak mungkin dihalangi sebab masyarakat dan negara terus berkembang dengan segala subsistem kemasyarakatan. ${ }^{1}$

Kekayaan desa yang berupa tanah desa tidak diperbolehkan dilakukan pelepasan hak kepemilikan kepada pihak lain, kecuali diperlukan untuk kepentingan umum. Pelepasan hak kepemilikan tanah desa untuk kepentingan umum dilakukan setelah mendapat ganti rugi sesuai harga yang menguntungkan desa dengan memperhatikan harga pasar dan Nilai Jual Objek Pajak (NJOP). Penggantian ganti rugi berupa uang harus digunakan untuk membeli tanah lain yang lebih baik dan berlokasi di desa setempat. Pelepasan hak kepemilikan tanah desa tersebut ditetapkan dengan keputusan kepala desa. Keputusan kepala desa diterbitkan setelah mendapat persetujuan BPD dan mendapat izin tertulis dari bupati/wali kota dan gubernur. Tata cara pengelolaan kekayaan desa diatur dengan peraturan bupati/wali kota. ${ }^{2}$ Di Daerah Istimewa Yogyakarta hal ini diatur dalam Peraturan Gubernur Daerah Istimewa Yogyakarta Nomor 34 Tahun 2017 tentang Pemanfaatan Tanah Desa dalam Pasal 44 yang disebutkan bahwa :3

Tanah Desa dapat dilepaskan untuk: pembangunan bagi kepentingan umum; pengganti tanah masyarakat yang terkena pengadaan tanah bagi pembangunan untuk kepentingan umum; kepentingan relokasi hunian karena terjadi bencana; dan/atau tukar-menukar atau penjualan Tanah Desa sebagai upaya penyelesaian permasalahan Tanah Desa. Persyaratan Pelepasan Tanah desa juga disebutkan dalam Pasal 46 ayat (1) yang berbunyi: "Pelepasan Tanah Desa sebagaimana dimaksud dalam Pasal 44, harus memenuhi persyaratan sebagai berikut: ${ }^{4}$ izin dari Kasultanan atau Kadipaten; dan menyediakan tanah pengganti yang senilai dengan Tanah Desa yang dilepaskan."

\footnotetext{
${ }^{1}$ Winahyu Erwiningsih, Hak. Menguasai Negara Atas Tanah, Kreasi Total Media, Yogyakarta, 2009, hlm. 181.

${ }^{2}$ Hanif Nurcholis, Pertumbuban dan Penyelenggaraan Pemerintaban Desa, Erlangga, Jakarta, 2011, hlm. 95.

3 Peraturan Gubernur Daerah Istimewa Yogyakarta Nomor 34 Tahun 2017 tentang Pemanfaatan Tanah Desa.

${ }^{4}$ Ibid, Pasal 46.
} 
Kegiatan tukar-menukar Tanah Kas Desa dengan Tanah Hak Milik penduduk yang dilakukan antara Pemerintah Desa dengan masyarakat merupakan hal yang sering terjadi dalam kehidupan bermasyarakat sehari-hari di Daerah Istimewa Yogyakarta, namun dalam pelaksanaannya timbul banyak permasalahan terutama pada pelaksanaan tukar-menukar yang dilakukan sebelum tahun 1985 hingga kini belum dapat terselesaikan, dikarenakan pada masa itu administrasi dibidang pertanahan belum tertata seperti sekarang dan UUPA baru diterapkan di Yogyakarta pada 1984 dan efektif berlaku pada 1985.

Pada masa lampau kegiatan tukar-menukar yang dilakukan oleh Pemerintah Desa dengan Warga sering hanya dilakukan secara lisan berdasarkan kesepakatan dan saling percaya, proses tukar-menukar tidak diselesaikan hingga memperoleh Izin Dari Kasultanan dan Kadipaten, sehingga sampai saat ini tanah yang kini dikuasai oleh warga tersebut masih tercatat sebagai Tanah Kas Desa dan tidak dapat dilakukan pensertifikatan oleh para warga yang menguasai tanah tersebut.

Seperti halnya yang terjadi pada para warga Desa Pendowoharjo, Kecamatan Sleman, Kabupaten Sleman, yang kini menempati bidang-bidang bekas Tanah Kas Desa tersebut hingga kini tidak dapat mensertifikatkan tanah mereka, hal ini berlangsung hingga turun temurun bahkan banyak bidang tanah bekas Tanah Kas Desa tersebut yang dijual atau dialihkan oleh para ahli waris kepada pihak lain dengan cara perikatan jual-beli dibawah tangan tanpa melalui Pejabat Pembuat Akta tanah (PPAT).

Oleh karena itu, penulis merasa perlu untuk mengetahui bagaimana upaya perlindungan hukum terhadap para penjual dan pembeli bekas tanah desa yang dilakukan dengan perjanjian bawah tangan karena memang secara prosedural belum dapat dilakukan pensertifikatan maupun jual-beli di hadapan PPAT dikarenakan belum selesainya proses tukar menukar antara Pemerintah Desa dengan warga yang pemilik tanah bekas tanah desa tersebut.

\section{Rumusan Masalah}

Berdasarkan uraian diatas dapat dirumuskan permasalahannya sebagai berikut: Pertama, bagaimanakah perlindungan hukum bagi para penjual dan pembeli terhadap jual beli hak atas tanah bekas tanah kas desa di desa Pendowoharjo yang dibuat secara di bawah tangan? Kedua, bagaimana peran notaris dalam penyelesaian jual beli hak atas tanah bekas tanah kas desa Pendowoharjo yang dibuat di bawah tangan? 


\section{Tujuan Penelitian}

Adapun tujuan penelitian ini: Pertama, mengetahui perlindungan hukum bagi para penjual dan pembeli terhadap jual beli hak atas tanah bekas tanah kas desa di desa Pendowoharjo yang dibuat secara di bawah tangan; dan Kedua, mengetahui peran notaris dalam penyelesaian jual beli hak atas tanah bekas tanah kas desa Pendowoharjo yang dibuat di bawah tangan.

\section{Metode Penelitian}

Jenis penelitian ini adalah penelitian hukum empiris yang dengan kata lain adalah jenis penelitian hukum sosiologis dan dapat disebut pula dengan penelitian lapangan, yaitu mengkaji ketentuan hukum yang berlaku serta apa yang terjadi dalam kenyataanya di masyarakat ${ }^{5}$. Jenis penelitian yuridis-empiris, yang akan bertumpu pada data primer atau hasil dari penelitian lapangan. Pendekatan yuridis empiris ini digunakan penulis untuk mengetahui proses penyelesaian dan kendala-kendala yang dihadapi dalam pelaksanaan tukar menukar tanah kas desa dengan tanah milik warga di desa Tridadi dan desa Pendowoharjo, Kecamatan Sleman. Subjek penelitian yang dijadikan sebagai rujukan dalam penelitian ini adalah pihak-pihak yang dipilih peneliti untuk memperoleh informasi dan keterangan terhadap masalah yang akan diteliti antara lain adalah : a) Kepala dan Pejabat-pejabat Kantor Dinas Pertanahan dan Tata ruang Kabupaten Sleman. b) Kepala Desa Pendowoharjo. c) Notaris / PPAT di Kabupaten Sleman. d) Warga yang menjadi penjual/pembeli Tanah bekas Tanah Desa di Desa Pandowoharjo Sleman.

\section{Hasil Penelitian dan Pembahasan}

Menurut Fitzgerald sebagaimana dikutip Satjipto Raharjo, awal mula dari munculnya teori perlindungan hukum ini bersumber dari teori hukum alam atau aliran hukum alam. Aliran ini dipelopori oleh Plato, Aristoteles (murid Plato), dan Zeno (pendiri aliran Stoic). Menurut aliran hukum alam menyebutkan bahwa hukum itu bersumber dari Tuhan yang bersifat universal dan abadi, serta antara hukum dan moral tidak boleh dipisahkan. Para penganut aliran ini memandang bahwa hukum dan moral adalah cerminan dan aturan secara internal dan eksternal dari kehidupan manusia yang diwujudkan melalui hukum dan moral. ${ }^{6}$

\footnotetext{
${ }^{5}$ Bambang Waluyo, Penelitian Hukum Dalam Praktek, Sinar Grafika, Jakarta, 2002, hlm. 15.

${ }^{6}$ Satjipto Raharjo, Ilmu Hukum, Citra Aditya Bakti, Bandung, 2000, hlm. 53.
} 
Perlindungan hukum adalah memberikan pengayoman kepada hak asasi manusia yang dirugikan orang lain dan perlindungan tersebut diberikan kepada masyarakat agar mereka dapat menikmati semua hak-hak yang diberikan oleh hukum atau dengan kata lain perlindungan hukum adalah berbagai upaya hukum yang harus diberikan oleh aparat penegak hukum untuk memberikan rasa aman, baik secara pikiran maupun fisik dari gangguan dan berbagai ancaman dari pihak manapun. ${ }^{7}$

Philipus M. Hadjon berpendapat bahwa “Prinsip perlindungan hukum bagi rakyat terhadap tindak pemerintah bertumpu dan bersumber dari konsep tentang pengakuan dan perlindungan terhadap hak-hak asasi manusia karena menurut sejarahnya di Barat, lahirnya konsep-konsep tentang pengakuan dan perlindugan terhadap hak-hak asasi manusia diarahkan ekpada pembatasan-pembatasan dan peletakan kewajiban pada masyarakat dan pemerintah. ${ }^{8}$

Menurut Hadjon, perlindungan hukum bagi rakyat meliputi dua hal, yakni: ${ }^{9}$ Perlindungan Hukum Preventif, yakni bentuk perlindungan hukum dimana kepada rakyat diberi kesempatan untuk mengajukan keberatan atau pendapatnya sebelum suatu keputusan pemerintah mendapat bentuk yang definitif; Perlindungan Hukum Represif, yakni bentuk perlindungan hukum dimana lebih ditujukan dalam penyelesaian sengketa.

Hubungan teori perlindungan hukum ini dengan permasalahan yang diangkat oleh penulis adalah untuk mengetahui wujud perlindungan hukum yang diberikan kepada para pihak dalam perikatan jual-beli tanah bekas tanah kas desa yang dibuat dibawah tangan.

JuaI-beli (menurut B.W.) adalah suatu perjanjian bertimbal balik dalam mana pihak yang satu (si penjual) berjanji untuk menyerahkan hak milik atas suatu barang, sedang pihak yang lainnya (si pembeli) berjanji untuk membayar harga yang terdiri atas sejumlah uang sebagai imbalan dari perolehan hak milik tesebut. Perkataan jual-beli menunjukkan bahwa dari satu pihak. perbuatan dinamakan menjual, sedangkan dari pihak yang lain dinamakan membeli. Istilah yang mencakup dua perbuatan yangbertimbal-balik.itu adalah sesuai dengan istilah Belanda "koop en verkoop" yang juga mengandung pengertian bahwa pihak yang satu "verkoopt" (menjual) sedang yang lainnya "koom" (membeli). Dalam bahasa Inggeris jual-beli disebut dengan hanya "sale" saja yang berarti

\footnotetext{
7 Satjipto Rahardjo, "Penyelenggaraan Keadilan Dalam Masyarakat Yang Sedang Berubah”, (1993) Jurnal Masalah Hukum.

8 Philipus M. Hadjon, Perlindungan Rakyat Bagi Rakyat di Indonesia: Sebuah Studi tentang Prinsip-Prinsipnya, Penanganannya oleh Pengadilan dalam Lingkungan Peradilan Umum dan Pembentukan Peradilan Administrasi Negara, Bina Ilmu, Surabaya, 1987, hlm. 38.

${ }_{9}$ Ibid., hlm. 4.
} 
"penjualan" (hanya dilihat dari sudutnya si penjual), begitu pula dalam bahasa Perancis disebuthanya dengan "vente" yang juga berarti "penjualan", sedangkan dalam bahasa Jerman dipakainya perkataan "Kauf" yang berarti "pembelian".

Barang yang menjadi obyek perjanjian jual-beli harus cukup tertentu, setidak-tidaknya dapat ditentukan ujud dan jumlahny: pada saat ia akan diserahkan hak miliknya kepada si pembeli. Dengan demikian adalah sah menurut hukum misalnya jual-beli mengenai panenan yang akan diperoleh pada suatu waktu dari sebidang tanah tertentu.

Pengalihan hak merupakan perpindahan hak terhadap sesuatu benda, baik benda bergerak maupun benda tidak bergerak. Pengalihan hak benda bergerak menurut KUH Perdata cukup dilakukan secara lisan, yakni sewaktu jual beli dilakukan si penjual langsung menyerahkan barangnya kepada si pembeli, maka pada saat itu hak terhadap benda tersebut telah beralih kepada si pembeli tersebut.

Sedangkan penyerahan barang yang tidak bergerak di samping dilakukan secara lisan, juga harus dilakukan dengan pembuatan suatu tulisan yang dinamakan dengan akta (surat penyerahan), yang dibuat secara resmi didepan notaris. Akta tersebut berupa suatu keterangan timbal-balik yang ditandatangani bersama oleh si penjual dan si pembeli, yang secara pokok berisi di satu pihak penjual menyerahkan hak miliknya, di pihak lain pembeli menyatakan menerima hak milik atau benda yang bersangkutan. ${ }^{10}$

Hak atas tanah dapat "dialihkan", yaitu berpindahnya hak atas tanah tertentu yang dilakukan dengan sengaja oleh pemilik lama kepada pihak lain yang memenuhi syarat dan sesuai dengan ketentuan yang berlaku. Bentuk peralihan hak atas tanah ini terbatas pada yang sudah ditetapkan, yaitu jual beli, tukar menukar, hibah, penyertaan modal dalam perusahaan, ruilslag (tukar bangun/tukar guling).

Sehubungan dengan peralihan hak atas tanah, maka dikenal juga beberapa macam peralihan hak atas tanah yaitu sebagai berikut: ${ }^{11}$ Jual beli tanah menurut Hukum Adat, adalah suatu perbuatan pemindahan hak atas tanah yang bersifat terang dan tunai. Terang berarti perbuatan pemindahan hak tersebut harus dilakukan dihadapan kepala adat, yang berperan sebagai pejabat yang menanggung keteraturan dan sahnya perbuatan pemindahan hak tersebut

\footnotetext{
${ }^{10}$ R. Subekti, Pokok-Pokok Hukum Perdata, Intermasa, Jakarta, 2001, hlm. 73.

${ }^{11}$ Adrian Sutedi, Peralihan Hak Atas Tanah dan Pendadftarannya, Sinar Grafika, Jakarta, 2010.
} 
sehingga perbuatan tersebut diketahui oleh umum. Tunai maksudnya, bahwa perbuatan pemindahan hak dan pembayaran harganya dilakukan secara serentak.

Jual beli tanah menurut UUPA, dalam UUPA istilah jual beli hanya disebutkan dalam Pasal 26 UUPA, yaitu yang menyangkut jual beli hak milik atas tanah. Dalam pasal-pasal lainnya, tidak ada kata yang menyebutkan jual beli, tetapi disebutkan sebagai dialihkan. Pengertian dialihkan menunjukkan suatu perbuatan hukum yang disengaja untuk memindahkan hak atas tanah kepada pihak lain melalui jual beli, hibah, tukar menukar, dan hibah wasiat. Jadi, meskipun dalam pasal hanya disebutkan dialihkan, termasuk salah satunya adalah perbuatan hokum pemindahan hak atas tanah karena jual beli.

Penghibahan tanah, hibah tanah merupakan pemberian seseorang kepada orang lain dengan tidak ada penggantian apa pun dan dilakukan secara sukarela, tanpa ada kontraprestasi dari pihak penerima pemberian, dan pemberian itu dilangsungkan pada saat si pemberi masih hidup. Inilah yang berbeda dengan wasiat, yang mana wasiat diberikan sesudah si pewasiat meninggal dunia.

Pewarisan tanah, perolehan hak milik atas tanah dapat juga terjadi karena pewarisan dari pemilik kepada ahli waris sesuai dengan Pasal 26 UUPA. Pewarisan dapat terjadi karena ketentuan undang-undang ataupun karena wasiat dari orang yang mewasiatkan.

Sehubungan dengan jual-beli hak atas tanah, di Indonesia dikenal dua macam jual-beli hak atas tanah sebagai berikut: menurut Hukum Adat, jual beli tanah adalah suatu perbuatan pemindahan hak atas tanah yang bersifat terang dan tunai. Terang berarti perbuatan pemindahan hak tersebut harus dilakukan di hadapan kepala adat, yang berperan sebagai pejabat yang menanggung keteraturan dan sahnya perbuatan pemindahan hak tersebut sehingga perbuatan tersebut diketahui oleh umum. Tunai maksudnya, bahwa perbuatan pemindahan hak dan pembayaran harganya dilakukan secara serentak. Oleh karena itu, maka tunai mungkin berarti harga tanah dibayar secara kontan, atau baru dibayar sebagian (tunai dianggap tunai). Dalam hal pembeli tidak membayar sisanya, maka penjual tidak dapat menuntut atas dasar terjadinya jual beli tanah, akan tetapi atas dasar hukum utang piutang.

Adapun prosedur jual beli tanah itu diawali dengan kata sepakat antara calon penjual dengan calon pembeli mengenai objek jual belinya yaitu tanah hak milik yang akan dijual dan harganya. Hal ini dilakukan melalui musyawarah di antara mereka sendiri. Setelah mereka sepakat akan harga dari tanah itu, biasanya sebagai tanda jadi, diikuti dengan pemberian panjer. Pemberian panjer tidak diartikan sebagai harus dilaksanakan jual beli itu. Dengan demikian panjer di sini fungsinya adalah hanya sebagai tanda jadi akan dilaksanakannya jual beli. 
Dengan adanya panjer, para pihak akan merasa mempunyai ikatan moral untuk melaksanakan jual beli tersebut. Apabila telah ada panjer, maka akan timbul hak ingkar. Bila yang ingkar si pemberi panjer, panjer menjadi milik penerima panjer, Sebaliknya, bila keingkaran tersebut ada pada pihak penerima panjer, panjer harus dikembalikan kepada pemberi panjer. Jika para pihak tidak menggunakan hak ingkar tersebut, dapatlah diselenggarakan pelaksanaan jual beli tanahnya, dengan calon penjual dan calon pembeli menghadap Kepala Desa (Adat) untuk menyatakan maksud mereka itu. Inilah yang dimaksud dengan terang. Kemudian oleh penjual dibuat suatu akta bermeterai yang menyatakan bahwa benar ia telah menyerahkan tanah miliknya untuk selamalamanya kepada pembeli dan bahwa benar ia telah menerima harga secara penuh. Akta tersebut turut ditandatangani oleh pembeli dan Kepala Desa (Adat). Dengan telah ditandatanganinya akta tersebut, maka perbuatan jual beli itu selesai. Pembeli kini menjadi pemegang hak atas tanahnya yang baru dan sebagai tanda buktinya adalah surat jual beli tersebut.

Dalam UUPA istilah jual beli hanya disebutkan dalam Pasal 26 yaitu yang menyangkut jual beli hak milik atas tanah. Dalam pasal-pasal lainnya, tidak ada kata yang menyebutkan jual beli, tetapi disebutkan sebagai dialihkan. Pengertian dialihkan menunjukkan suatu perbuatan hukum yang disengaja untuk memindahkan hak atas tanah kepada pihak lain melalui jual beli, hibah, tukarmenukar, dan hibah wasiat. Jadi, meskipun dalam pasal hanya disebutkan dialihkan, termasuk salah satunya adalah perbuatan hukum pemindahan hak atas tanah karena jual beli.

Menurut Pasal 19 PP No. 10/1961 setiap perjanjian yang bermaksud memindahkan hak atas tanah, harus dibuktikan dengan akte Penjabat Pembuat Akte Tanah (PPAT). Jadi jual-beli hak atas tanah harus dilakukan di hadapan PPAT. Sebagai bukti bahwa telah terjadi jual-beli suatu hak atas tanah, PPAT membuat akte jual-beli.

Hak Pengelolaan tidak dapat dijual, sedangkan Hak Gadai, sampai saat ini dalam praktek belum'didaftar. Maka praktis jual-beli hak atas tanah yang objeknya Hak Milik, Hak Guna Usaha, Hak Guna Bangunan dan Hak Pakai atas tanah negara saja yang harus dilakukan di hadapan PPAT. Sedangkan jual-beli Hak Pakai dan Hak Sewa atas tanah perseorangan tidak harus dilakukan di hadapan PPAT, tetapi dapat dilakukan di mana saja dan dibuatkan akte di bawah tangan atau akte notaris. Di hadapan PPAT yang mana dilakukan jual-beli itu? 
Yaitu di hadapan PPAT yang daerah kerjanya meliputi wilayah dimana tanah yang dijual itu terletak (Pasal 2 PMA no. 10/1961).12

Mengenai pengertian akta, dalam hukum Romawi akta disebut sebagai gesta atau instrumenta forensia, juga disebut sebagai publica monumenta atau akta publica. Akta-akta tersebut dibuat oleh seorang pejabat publik (publicae personae). Dari berbagai kata tersebut di atas kemudian muncul kata-kata publicare dan insinuari, actis inseri, yang artinya mendaftarkan secara publik. ${ }^{13}$

Menurut A.Pitlo akta itu sebagai surat-surat yang ditandatangani, dibuat untuk dipakai sebagai bukti, dan dipergunakan oleh orang, untuk keperluan siapa surat itu dibuat. Kemudian menurut Sudikno Merto kusumo akta adalah surat yang diberi tanda tangan, yang memuat peristiwa-peristiwa, yang menjadi dasar dari suatu hak atau perikatan, yang dibuat sejak semula dengan sengaja untuk pembuktian ${ }^{14}$

Dalam teori hukum dikenal 2 jenis akta, yaitu akta autentik dan akta di bawah tangan. Pengertian akta otentik dapat ditemukan dalam Pasal 1868 KUHPer yaitu akta yang di dalam bentuk yang ditentukan oleh undang-undang, dibuat oleh atau di hadapan pegawai-pegawai umum yang berkuasa untuk itu di tempat di mana akta itu dibuatnya atau dengan kata lain akta otentik adalah akta yang dibuat oleh pejabat yang diberi wewenang untuk itu oleh penguasa menurut ketentuan-ketentuan yang telah ditetapkan baik dengan maupun tanpa bantuan dari yang berkepentingan, yang mencatat apa yang dimintakan untuk dimuat di dalamnya oleh yang berkepentingan ${ }^{15}$

Alat bukti di bawah tangan tidak diatur dalam HIR, namun diatur dalam Staatsblad 1867 No. 29 untuk Jawa dan Madura, dan Pasal 1286 sampai Pasal 305 RBg. Akta di bawah tangan diakui dalam KUH Perdata. Dalam Pasal 1320 telah ditentukan syarat sahnya perjanjian. Dilihat dari 4 syarat sah yang dimaksud, dapat ditafsirkan bahwa suatu akta yang tidak dibuat oleh dan di hadapan PPAT adalah tetap sah sepanjang para pihak telah sepakat dan memenuhi unsur-unsur dalam Pasal 1320 KUH Perdata. Fungsi akta ada 2, yaitu fungsi formal yang menentukan lengkapnya (bukan untuk sahnya), dan fungsi akta sebagai alat bukti di kemudian hari.

Akta di bawah tangan ialah setiap akta yang dibuat tanpa perantara seorang pejabat umum, yang mana pembuktiannya dapat memiliki kekuatan pembuktian yang sama dengan suatu akta autentik (argumentum per analogian/analogi)

\footnotetext{
12 Effendi Perangin, Praktek Jual Beli Tanah, Rajawali Press, Jakarta, 1987, hlm. 11.

${ }_{13}$ Muhammad Adam, Ilmu Pengetabuan Notariat, Sinar Baru, Bandung, 1985, hlm. 252.

${ }_{14}$ Daeng Naja, Teknik Pembuatan Akta, Pustaka Yustisia,Yogyakarta,2012, hlm. 1.

15 Sudikno Mertokusumo, Hukum Acara Perdata Indonesia, Edisi Keempat, Liberty, Yogyakarta, 1993, hlm.
} 121. 
apabila pihak yang menandatangani surat perjanjian itu tidak menyangkal tanda tangannya, yang berarti ia tidak menyangkal kebenaran apa yang tertulis dalam surat perjanjian itu. Namun, apabila antara pihak-pihak yang melakukan perjanjian tersebut ada yang menyangkal tanda tangannya, maka pihak yang mengajukan surat perjanjian tersebut diwajibkan untuk membuktikan kebenaran penandatanganan atau isi akta tersebut. ${ }^{16}$

Sedangkan pada akta autentik memiliki kekuatan pembuktian yang sempurna, karena akta tersebut dibuat oleh pejabat yang berwenang. Sempurna disni berarti ialah akta tersebut dengan sendirinya dapat membuktikan dirinya sebagai akta autentik, dapat membuktikan kebenaran dari apa yang disaksikan oleh pejabat umum, dan akta itu berlaku sebagai yang benar diantara para pihak dan para ahli waris serta para penerima hak mereka. Akta autentik apabila dipergunakan di muka pengadilan adalah sudah cukup bagi hakim tanpa harus maminta alat bukti lainnya. ${ }^{17}$

Pada sekitar 1966 Pemerintah daerah Kabupaten Sleman akan membuat korebang atau kolam renang dan komplek pembangunan di sekitar Pasar Denggung dan sekitarnya yang sekarang telah menjadi beberapa bangunan diantaranya gedung serbaguna, gedung kesenian komplek TPR dan Pengadilan Negeri ke utara sampai Komisi Pemilihan Umum tanah tersebut awalnya milik warga Pedukuhan Jaban Tridadi Sleman sekitar 12 warga dengan luas sekitar $20.728 \mathrm{~m}^{2}$ selanjutnya ke dua belas warga tersebut mendapatkan tanah pengganti di Desa Pandowoharjo dengan menggunakan tanah kas desa Pandowoharjo disekitar Dusun Jetakan dan Sawahan seluas $18.540 \mathrm{~m}^{2}$ kondisi tanah pada waktu itu memang tanah kas Desa yang sangat subur sementara tanah-tanah warga yang berada di Jaban Tridadi hanya merupakan tanah kering yang tidak bisa untuk pertanian. ${ }^{18}$

Tabel 1.

Tanah Warga Jaban Tridadi Sleman yang digunakan untuk Kawasan Perkantoran Pemerintah Kabupaten Sleman

\begin{tabular}{|c|c|c|c|c|c|}
\hline No. & Nama & Persil & Klas & Luas & Keterangan \\
\hline & Painem & 153 & S V & 715 & Total Luas \\
\hline & & 75 & & 670 & $3205 \mathrm{~m} 2$ \\
\hline & & 75 & & 440 & C No. 391 \\
\hline
\end{tabular}

${ }^{16}$ R. Subekti, Op. Cit., hlm. 139.

${ }_{17}$ Salim Hs, 2011, Perancangan Kontrak \& Memorandum Of Understanding (MOU), Sinar

Grafika, Jakarta, hlm. 39-40.

${ }^{18}$ Hasil Wawancara dengan Muthohar, Kepala Seksi Sengketa Pertanahan, Dinas Pertanahan dan Tata ruang Kabupaten Sleman, Tanggal 10 Februari 2020 


\begin{tabular}{|c|c|c|c|c|c|}
\hline & & 153 & & 685 & \\
\hline & & 153 & & 695 & \\
\hline \multirow[t]{4}{*}{2.} & Ponidi & 148 & S V & 470 & Total Luas \\
\hline & & 150 & & 1515 & $2280 \mathrm{~m} 2$ \\
\hline & & 151 & & 15 & C No. 89 \\
\hline & & 152 & & 280 & \\
\hline \multirow[t]{5}{*}{3.} & Atmo Suhardjo & 150 & S V & 75 & Total Luas \\
\hline & & 153 & & 720 & $2800 \mathrm{~m} 2$ \\
\hline & & 153 & & 950 & C No. 363 \\
\hline & & 156 & & 495 & \\
\hline & & 75 & & 560 & \\
\hline \multirow[t]{3}{*}{4.} & B. Atmo Suhardjo & 153 & S V & 1160 & Total Luas \\
\hline & & 156 & & 853 & 2013 m2 \\
\hline & & & & & C No. 153 \\
\hline \multirow[t]{3}{*}{5.} & B. Marto Shuardjo & 156 & S V & 785 & Total Luas \\
\hline & & & & & $785 \mathrm{~m} 2$ \\
\hline & & & & & C No 233 \\
\hline \multirow[t]{2}{*}{6.} & Ny. Mangun Pawiro & 153 & S V & 330 & Total Luas \\
\hline & & & & & $330 \mathrm{~m} 2$ \\
\hline \multirow[t]{3}{*}{7.} & Sardiyono & 156 & S V & 205 & Total Luas \\
\hline & & 75 & & 930 & $1135 \mathrm{~m} 2$ \\
\hline & & & & & C No 210 \\
\hline \multirow[t]{3}{*}{8.} & Suratman & 75 & S V & 620 & Total Luas \\
\hline & & 153 & & 540 & $1160 \mathrm{~m} 2$ \\
\hline & & & & & C No. 139 \\
\hline \multirow[t]{3}{*}{9.} & Ny. Sutian & 153 & S V & 325 & Total Luas \\
\hline & & & & & $325 \mathrm{~m} 2$ \\
\hline & & & & & C No. 440 \\
\hline \multirow[t]{3}{*}{10.} & Sukiana Triatmaja & 153 & S V & 325 & Total Luas \\
\hline & & & & & $325 \mathrm{~m} 2$ \\
\hline & & & & & C No. 439 \\
\hline \multirow[t]{4}{*}{11.} & Suradi & 150 & S V & 885 & Total Luas \\
\hline & & 153 & & 640 & $2380 \mathrm{~m} 2$ \\
\hline & & 153 & & 505 & C No. 209 \\
\hline & & 75 & & 350 & \\
\hline \multirow[t]{3}{*}{12.} & Sugiman & 75 & S V & 2600 & Total Luas \\
\hline & & & & & $2600 \mathrm{~m} 2$ \\
\hline & & & & & C No. 131 \\
\hline
\end{tabular}


Seiring perjalanan waktu ternyata proses peralihan tidak ditindaklanjuti dengan proses administrasi peralihan hak atas tanah, sehingga warga Jaban yang selama hampir 50 tahun hanya menggarap saja dan belum memiliki sertipikat kepemilikan, sedang Pemerintah Desa Pandowoharjo juga belum memiliki sertipikat tanah kas desa yang ada di Desa Tridadi sebagai tukar tanah warga Jaban yang sekarang dipakai untuk perkantoran, pasar dan gedung serbaguna yang semuanya dibawah pengelolaan Pemerintah Daerah Kabupaten Sleman. Penyelesaian masalah tukar-menukar ini hingga saat ini masih dalam proses, memerlukan waktu yang lama dan bahkan sempat terhenti. Akibat dari lamanya proses penyelesaian administrasi tukar-menukar Tanah Desa dengan Tanah Warga, seiring berjalannya waktu ada beberapa warga yang telah menjual tanah pengganti tersebut kepada Pihak lain, sedangkan tanah yang dijual tersebut masih dalam proses penyelesaian tukar menukar, sehingga belum dapat diterbitkan sertifikat hak miliknya, dari 12 warga Jaban yang mendapat tanah pengganti di Desa Pandowoharjo, tercatat 4 warga telah mengalihkan atau menjual tanah tersebut kepada pihak lain.

Sebagai upaya perlindungan hukum Pemerintah Desa Pandowoharjo berinisiatif untuk memfasilitasi para warga tersebut untuk membuat perjanjian jual beli secara di bawah tangan dengan disaksikan oleh Perangkat Desa dan Kepala Desa, untuk sementara waktu hal ini dilakukan untuk menghindari terjadinya sengketa dikemudian hari, sembari menunggu proses administrasi tukar-menukar tersebut diselesaikan hingga dapat diterbitkan sertifikat. ${ }^{19}$

Hasil wawancara penulis dengan warga yang telah membeli dan menguasai bekas tanah kas desa tersebut, para pembeli tidak dapat melakukan proses jual beli tanah melalui Pejabat Pembuat Akta Tanah, karena tanah tersebut belum dapat diterbitkan sertifikat dan masih tercatat sebagai tanah kas desa, oleh karena itu hanya dapat dilakukan jual beli di bawah tangan dengan disaksikan oleh perangkat Desa dan diketahui oleh Kepala Desa saat itu. ${ }^{20}$

Mengenai kekuatan perjanjian di bawah tangan, perjanjian di bawah tangan tetap berlaku sepanjang sesuai kaidah Pasal 1320 Kitab Undang-undang Hukum Perdata tentang syarat sahnya perjanjian dan sepanjang para pihak mengakuinya, maka perjanjian tersebut berlaku seperti undang-undang bagi para pihak yang mengikatkan dirinya, namun apabila ada salah satu pihak yang mengingkari perjanjian tersebut, maka pembuktiannya harus didukung dengan data

\footnotetext{
${ }^{19}$ Ibid.

20 Hasil Wawancara dengan V. Lili Rismiyanto, Wahyudi Yanto dan Kargiyanto, Warga yang telah membeli tanah bekas tanah kas desa pandowoharjo, pada tanggal 4 Februari 2020. Pukul 11.00
} 
pendukung lain yang dapat memperkuat perjanjian tersebut dan keputusannya diserahkan pada pertimbangan Hakim. ${ }^{21}$

Dari uraian di atas dapat penulis ketahui bahwa jual beli hak atas tanah Bekas tanah kas Desa Pandowoharjo tersebut tidak dilakukan melalui PPAT sesuai dengan Peraturan Pemerintah Nomor 24 Tahun 1997, hal ini dikarenakan proses administrasi tukar-menukar dengan Pemerintah Desa Pandowoharjo belum selesai hingga saat ini, bahkan sempat terhenti, oleh karena itu proses jual-beli hak atas tanah tersebut hanya dilakukan secara di bawah tangan, dengan perangkat desa sebagai saksi, dan diketahui oleh Kepala Desa. Proses jual beli hak atas tanah bekas tanah kas desa yang dibuat secara di bawah tangan tersebut ditambah lagi dengan penyelesaian tukar-menukarnya yang memakan waktu lama bahkan sempat terhenti, tentu terdapat resiko terjadinya sengketa di kemudian hari, seperti apabila salah satu Pihak dari Jual Beli tersebut mengingkari/ menyangkal perjanjian tersebut, mengaku tidak pernah menanda-tangani perjanjian tersebut, atau menanda-tangani tetapi tidak mengerti isinya, maka akan diperlukan bukti pendukung lain atau data yang dapat memperkuat perjanjian tersebut.

Sebagaimana terdapat dalam Pasal 15 ayat (2) huruf a Undang-undang Nomor 2 Tahun 2014 tentang Perubahan Undang-Undang Nomor 30 Tahun 2004 tentang Jabatan Notaris, Notaris memiliki salah satu wewenang mengesahkan tanda tangan dan menetapkan kepastian tanggal surat di bawah tangan, para pihak melakukan penandatanganan perjanjian di bawah tangan di hadapan notaris sehingga notaris dapat mengesahkan tanda tangan dan tanggal penandatanganan. 22

Dalam prakteknya sering ditemukan surat-surat di bawah tangan yang dikuatkan oleh pejabat yang tidak berwenang untuk itu misalnya Lurah, dimana dalam perjanjian jual beli tanah, masyarakat sering meminta lurah untuk memberikan penguatan sebagai yang "mengetahui" terhadap perjanjian yang mereka lakukan, hal ini terjadi karena memang dahulu lurah dipandang memiliki kekuasaan yang tinggi sedangkan keberadaan notaris dan PPAT belum sebanyak saat ini. ${ }^{23}$

Dalam dunia kenotariatan, surat di bawah tangan dibagi menjadi dua yaitu surat di dibawah tangan yang didaftarkan baik melalui legalisasi maupun waarmerk dan surat di bawah tangan yang tidak didaftarkan. Surat di bawah tangan yang didaftarkan melalui legalisasi yaitu surat di bawah tangan yang belum ditandatangani, diberikan kepada notaris dan dihadapan notaris

${ }^{21}$ Hasil Wawancara dengan Herlina Susanti, Notaris Di Kabupaten Sleman Pada Tanggal 7 Juli 2020, Pukul 13.00.

22Undang-undang Nomor 2 Tahun 2014 tentang perubahan Undang-Undang Nomor 30 Tahun 2004 tentang Jabatan Notaris.

${ }^{23}$ Hasil Wawancara dengan Sukarno, Notaris di Kabupaten Sleman, pada tanggal 6 Juli 2020, Pukul 10.00 . 
ditandatangani oleh para pihak yang bersangkutan setelah isi akta dijelaskan oleh notaris kepada mereka. Pada legalisasi, tanda tangannya dilakukan dihadapan Notaris yang melegalisasi. ${ }^{24}$

Legalisasi merupakan proses peningkatan kekuatan pembuktian suatu surat di bawah tangan, Pertanggungjawaban notaris atas kebenaran akta di bawah tangan yang dilegalisasinya adalah notaris menjamin kepastian tanda tangan artinya pasti bahwa yang tanda tangan itu memang pihak dalam perjanjian, bukan orang lain. Maka dari itu, notaris disyaratkan mengenal orang yang menandatangani tersebut dengan cara melihat identitas diri para pihak melalui Kartu tanda penduduk, SIM, dan lain-lain, kemudian dibacakan isi dari perjanjuan tersebut, barulah mereka membubuhkan tandatangannya dihadapan yang notaris melegalisasi pada saat, hari dan tanggal itu juga. ${ }^{25}$

Dari uraian di atas dapat diketahui bahwa dalam prakteknya sering ditemukan surat di bawah tangan yang dikuatkan oleh pejabat yang tidak berwenang untuk hal itu, seperti yang terjadi pada perjanjian jual beli bekas Tanah Kas Desa Pandowoharjo yang dibuat di bawah tangan tersebut, dalam hal ini dikuatkan dengan Lurah/ Kepala Desa sebagai yang "mengetahui", padahal Sebagaimana terdapat dalam Pasal 15 ayat (2) huruf a Undang-Undang Nomor 2 Tahun 2014 tentang Perubahan Undang-Undang Nomor 30 Tahun 2004 tentang Jabatan Notaris, Notarislah yang memiliki kewenangan untuk mengesahkan tanda tangan dan menetapkan kepastian tanggal surat di bawah tangan.

Surat di bawah tangan yang mendapat legalisasi notaris, terhadap surat tersebut notaris menjamin mengenai kebenaran dari kepastian tanda tangan artinya pasti bahwa yang tanda tangan itu memang pihak dalam perjanjian, bukan orang lain, dan para pihak yang bertanda tangan tidak dapat mengatakan kalau tidak mengerti apa isi surat itu, karena telah dibacakan oleh notaris, sehingga apabila di kemudian hari terjadi sengketa, surat di bawah tangan yang telah dilegalisasi notaris dapat membantu hakim dalam memperoleh kepastian mengenai tanggal dan identitas para pihak.Oleh karena itu, dalam upaya perlindungan hukum terhadap Jual beli bekas Tanah Kas Desa Pandowoharjo, Peran notaris dapat dilibatkan dalam hal memperkuat alat bukti perjanjian tersebut melalui legalisasi surat di bawah tangan.

\footnotetext{
${ }^{24}$ A. Kohar, Notaris Berkomunikasi, Alumni, Bandung, 1984, hlm. 34.

${ }^{25}$ Hasil wawancara dengan Fauzi Heryanto, Notaris di Kabupaten Sleman, pada tanggal 6 Januari 2020, Pukul 16.00.
} 


\section{Penutup}

Berdasarkan pembahasan sebelumnya maka dapat ditarik kesimpulan, bahwa perlindungan hukum bagi penjual dan pembeli terhadap jual beli hak atas tanah bekas tanah kas desa Pandowoharjo yang dilakukan di bawah tangan, ditemukan pada Pemerintah Desa Pandowoharjo yang telah berinisiatif untuk memfasilitasi para warga yang melakukan jual beli tersebut tersebut untuk membuat perjanjian jual beli secara di bawah tangan dengan disaksikan oleh Perangkat Desa dan diketahui Kepala Desa, untuk sementara waktu hal ini dilakukan untuk menghindari terjadinya sengketa dikemudian hari, sembari menunggu proses administrasi tukar-menukar tersebut diselesaikan hingga dapat diterbitkan sertifikat.

Peran notaris dapat dilibatkan dalam hal memperkuat alat bukti perjanjian dibawah tangan melalui legalisasi surat di bawah tangan, sebagaimana terdapat dalam Pasal 15 ayat (2) huruf a Undang-Undang Nomor 2 Tahun 2014 tentang Perubahan Undang-Undang Nomor 30 Tahun 2004 tentang Jabatan Notaris, Notarislah yang memiliki kewenangan untuk mengesahkan tanda tangan dan menetapkan kepastian tanggal surat di bawah tangan. Surat di bawah tangan yang mendapat legalisasi notaris, terhadap surat tersebut notaris menjamin mengenai kebenaran dari kepastian tanda tangan artinya pasti bahwa yang tanda tangan itu memang pihak dalam perjanjian, bukan orang lain, dan para pihak yang bertanda tangan tidak dapat mengatakan kalau tidak mengerti apa isi surat itu, karena telah dibacakan oleh notaris, sehingga apabila di kemudian hari terjadi sengketa, surat di bawah tangan yang telah dilegalisasi notaris dapat membantu hakim dalam memperoleh kepastian mengenai tanggal dan identitas para pihak.Oleh karena itu, dalam upaya perlindungan hukum terhadap jual beli bekas Tanah Kas Desa Pandowoharjo, Peran notaris dapat dilibatkan dalam hal memperkuat alat bukti perjanjian tersebut melalui legalisasi surat di bawah tangan.

\section{Daftar Pustaka}

\section{Buku}

Adam, Muhammad, Ilmu Pengetahuan Notariat, Sinar Baru, Bandung, 1985.

Peranginangin, Effendi, Praktek Jual Beli Tanah, Rajawali Press, Jakarta, 1987.

Erwiningsih, Winahyu, Hak Menguasai Negara Atas Tanah, Kreasi Total Media, Yogyakarta, 2009.

H.S., Salim, Perancangan Kontrak \& Memorandum Of Understanding (MOU), Sinar Grafika, Jakarta, 2011.

Kohar, A. Notaris Berkomunikasi, Alumni, Bandung, 1984. 
Mertokusumo, Sudikno, Hukum Acara Perdata Indonesia, Liberty, Yogyakarta, 2006.

M. Hadjon, Philipus. Perlindungan Rakyat Bagi Rakyat di Indonesia: Sebuah Studi tentang Prinsip-Prinsipnya, Penanganannya oleh Pengadilan dalam Lingkungan Peradilan Umum dan Pembentukan Peradilan Administrasi Negara, Bina Ilmu, Surabaya, 1987.

Naja, Daeng. Teknik Pembuatan Akta, Pustaka Yustisia, Yogyakarta, 2012.

Nurcholis, Hanif, Pertumbuhan dan Penyelenggaraan Pemerintahan Desa, Erlangga, Jakarta, 2011.

Rahardjo, Satjipto, Ilmu Hukum, Citra Aditya Bakti, Bandung, 2000.

Subekti, R., Pokok-Pokok Hukum Perdata, Intermasa. Jakarta, 2001.

Sutedi, Adrian, Peralihan Hak Atas Tanah dan Pendadftarannya, Sinar Grafika. Jakarta, 2010.

Waluyo, Bambang, Penelitian Hukum Dalam Praktek, Sinar Grafika, Jakarta, 2002.

Jurnal

Rahardjo, Satjipto, "Penyelenggaraan Keadilan Dalam Masyarakat Yang Sedang Berubah”, (1993) Jurnal Masalah Hukum.

\section{Peraturan Perundang-undangan}

UU No. 2 Tahun 2014 Tentang Perubahan Atas Undang-Undang Nomor 30 Tahun 2004 tentang Jabatan Notaris.

Undang-Undang Nomor 13 Tahun 2012 tentang Keistimewaan Daerah Istimewa Yogyakarta

Undang-Undang Nomor 72 Tahun 2005 tentang Desa.

Undang-undang Nomor 20 Tahun 1961 tentang Pencabutan Hak-hak Tanah dan/atau Benda-benda yang Ada di Atasnya.

Undang-undang Republik Indonesia Nomor 5 Tahun 1960 Tentang Peraturan Dasar Pokok-pokok Agraria.

Undang-Undang Nomor 3 Tahun 1950 tentang Pembentukan Daerah Istimewa Yogyakarta

Peraturan Gubernur Daerah Istimewa Yogyakarta Nomor 34 Tahun 2017 tentang Pemanfaatan Tanah Desa.

\section{Wawancara}

Wawancara dengan Muthohar, Kepala Seksi Sengketa Pertanahan, Dinas Pertanahan dan Tata ruang Kabupaten Sleman, Tanggal 10 Februari 2020, Pukul 13.00.

Wawancara dengan Bapak Marjana, Kepala Seksi Pemerintahan Desa Pandowoharjo, pada tanggal 7 April 2020. Pukul 10.00. 
474 Ifx Renaissance NO. 2 VOL. 5 APRIL 2020: 458-474

Wawancara dengan V. Lili Rismiyanto, Wahyudi Yanto dan Kargiyanto, Warga yang telah membeli tanah bekas tanah kas desa pandowoharjo, pada tanggal 4 Februari 2020. Pukul 11.00.

Wawancara dengan Herlina Susanti, Notaris Di Kabupaten Sleman, Pada Tanggal 7 Juli 2020, Pukul 13.00.

Wawancara dengan Sukarno, Notaris di Kabupaten Sleman, pada tanggal 6 Juli 2020, Pukul 10.00.

Wawancara dengan Fauzi Heryanto, Notaris di Kabupaten Sleman, pada tanggal 6 Januari 2020, Pukul 16.00. 